\title{
FRONTAL BONE FRACTURES; AN ANALYSIS AT LIAQUAT UNIVERSITY HOSPITAL HYDERABAD.
}

1. BDS, MSc

Lecturer

Department of Oral \& Maxillofacia

Surgery

LUMHS, Jamshoro.

2. MBBS, FCPS

Assistant Professor Department of Neurosurgery

LUMHS, Jamshoro.

3. BDS, MSc Trained

Lecturer

Department of Oral \& Maxillofacial Surgery

LUMHS, Jamshoro.

4. BDS, FCPS (Trained)

Department of Oral \& Maxillofacial Surgery

Bhittai Dental \& Medical College

Mirpurkhas.

Correspondence Address:

Dr. Salman Shams

Department of Oral \& Maxillofacial

Surgery

LUMHS, Jamshoro.

Article received on:

18/07/2018

Accepted for publication:

24/09/2018

Received after proof reading:

22/05/2019

\begin{abstract}
Salman Shams ${ }^{1}$, Muhammad Hamid $\mathrm{Ali}^{2}$, Abdul Ghafar Shaikh ${ }^{3}$, Anand Kumar ${ }^{4}$
ABSTRACT... To analyze the pattern and presentation of frontal bone fractures at tertiary care hospital. Study Design: Prospective study. Setting: Department of Oral \& Maxillofacial Surgery \& Neurosurgery Liaquat University hospital Hyderabad. Period: Study was conducted from 2012 to 2017. Materials and Methods: 62 patients of frontal bone fractures with age range of 21 to 60 years. Clinical diagnosis was done by plain radiograph PA view of face and 3D CT scan of face. The parameters used to classify the patients were age and sex, etiology and site of trauma, presence of associated craniomaxillofacial fractures. Results: Males were involved more than females. Peak age range was found between 31 to 40 years (50\%) followed by 41 to 50 years (26.92\%). RTA was the most common etiological factor involved followed by assault. Fractures of anterior table were most frequently seen (59.61\%). Most frequently associated craniomaxillofacial involved was naso-orbito ethmoid fracture. Conclusion: This study concludes that RTA is the most contributing factor of frontal bone fracture. Fractures involving anterior table fracture are frequently seen, these fractures rarely occur in isolation and mostly seen with NOE type of craniomaxillifacial trauma.
\end{abstract}

Key words: $\quad$ Anterior Table, Craniomaxillofacial, Frontal Bone, Naso-orbito-ethmoid, RTA.

Article Citation: Shams S, Ali MH, Shaikh AG, Kumar A. Frontal bone fractures; an analysis at Liaquat University Hospital Hyderabad. Professional Med J 2019; 26(6):969-972. DOI: 10.29309/TPMJ/2019.26.05.3607

\section{INTRODUCTION}

Frontal bone fractures are infrequent and follow in only $5-12 \%$ of maxillofacial traumas and have a fairly low rate if compared to the residual types of fracture involving the cranio-maxillofacial region. ${ }^{1}$ Fractures linking this bone is considered to be pretty hazardous because of its juxtaposition to brain as well as due to the cosmetic blemishes it can produce. ${ }^{2}$ The most shared cause of frontal sinus fractures is high rapidity blunt energy trauma like traffic accidents, assault, falls etc. ${ }^{3,4}$

Frontal fractures are grouped into 3 different broad categories: Anterior table fracture, Posterior table fractures, Combined fractures, through and through fractures, fractures involving nasofrontal duct. ${ }^{5}$ Up to $66 \%$ of patients will have associated facial fractures. Isolated anterior table fractures occur $33 \%$ of the time. Combined fractures of the anterior table, posterior table, and/or the nasofrontal recess account for $67 \%$ of frontal sinus injuries. Isolated posterior table injuries are uncommon. ${ }^{6,7}$
Complex fractures can still result in enhancing and functional deformity. The current challenge is to consistently restore patients back to their preinjury form and function, but this is not always possible. Greater understanding and developments have significantly improved outcomes, although controversy still exists in some areas. ${ }^{8}$ The management of frontal sinus fractures varies among specialties. Neurosurgical complications may present acutely or may have a delayed presentation. In the acute period, the main concern is cerebrospinal fluid (CSF) leakage, with risk of subsequent seeding of infection and progression to meningitis or cerebritis. Delayed complications include brain abscess and mucocele formation. ${ }^{9}$

\section{MATERIAL \& METHODS}

Patients met the inclusion criteria came through Out Patient Department (OPD) or through Emergency Department of Liaquat University Hospital were involved in this research. 
Diagnosis of frontal bone fracture was done on the basis of clinical examination, radiography like P.A view of face \& 3D CT scan of face. Informed consent was taken from the patient. Patients demographic details were recorded like gender and age. Other variables recorded were cause of trauma, site of frontal bone fracture and any associated maxillofacial injury.

\section{RESULTS}

Out of 52 patients, 39 were males and 13 were females as shown in Figure-1

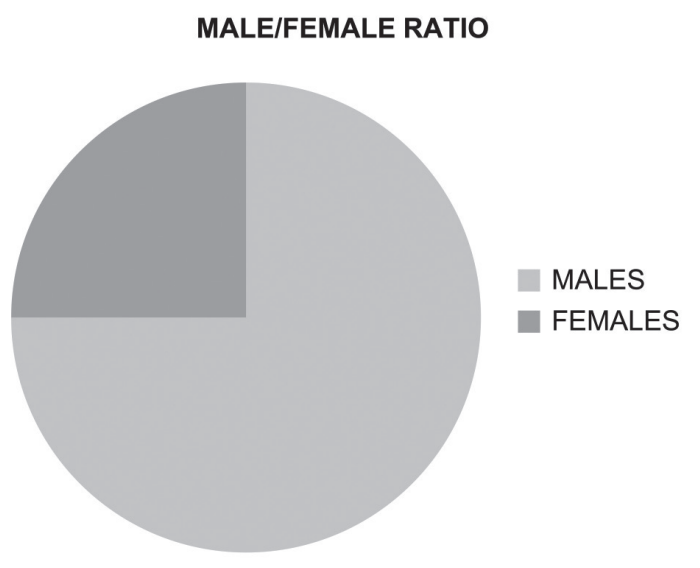

Figure-1. Male and female ratio

Most common age group involved was fourth decade of life as shown in Table-l.

\begin{tabular}{|l|c|c|}
\hline \multicolumn{1}{|c|}{ Age Group } & No of Patients & $\%$ \\
\hline 11 to 20 Years & 02 & $3.84 \%$ \\
\hline 21 - 30 Years & 06 & $11.53 \%$ \\
\hline 31 to 40 Years & 26 & $50 \%$ \\
\hline 41 to 50 Years & 14 & $26.92 \%$ \\
\hline 51 to 60 Years & 04 & $7.69 \%$ \\
\hline Total & 52 & $100 \%$ \\
\hline
\end{tabular}

Table-I. Showing details about age groups affected.

Road traffic accident was the most common etiological factor found in this research.

Anterior table fractures were commonly seen as shown in Table-II.

41 patients had associated maxillofacial trauma involving different bones as shown in TableIII. While 11 patients had isolated frontal bone fracture.

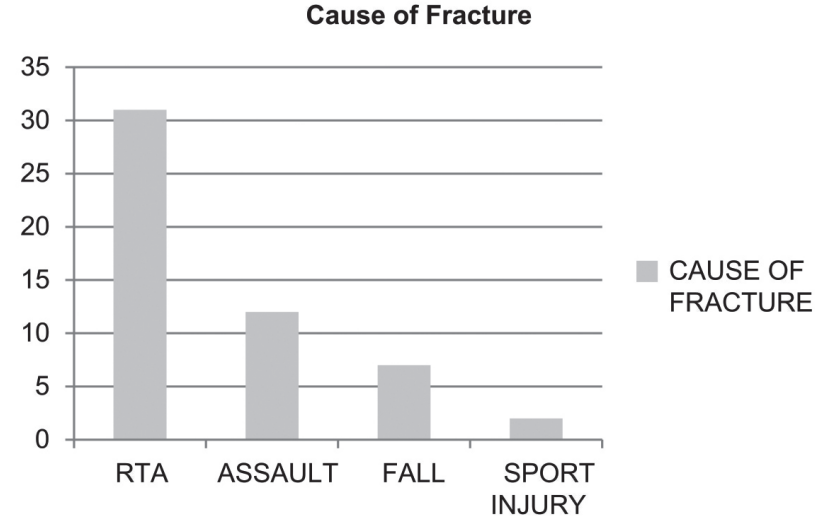

Figure-2. Showing different causes associated with frontal bone fracture

\begin{tabular}{|l|c|c|}
\hline \multicolumn{1}{|c|}{ Site } & $\begin{array}{c}\text { No. of } \\
\text { Patients }\end{array}$ & $\%$ \\
\hline Anterior Table Fracture & 31 & $59.61 \%$ \\
\hline Posterior Table Fracture & 01 & $1.92 \%$ \\
\hline Combined Fracture & 17 & $32.69 \%$ \\
\hline Through \& Through Fracture & 02 & $3.84 \%$ \\
\hline Involving Nasofrontal Duct & 01 & $1.92 \%$ \\
\hline Total & 52 & $100 \%$ \\
\hline
\end{tabular}

Table-Il. Showing details about site of fracture

\begin{tabular}{|l|c|}
\hline \multicolumn{1}{|c|}{ Associated Fracture } & No of Patients \\
\hline Naso-Orbito Ethmoid & 24 \\
\hline Zygomatic Complex & 13 \\
\hline Orbital Floor & 08 \\
\hline Lefort III & 09 \\
\hline Lefort II & 07 \\
\hline Nasal Bone & 11 \\
\hline Mandible & 07 \\
\hline
\end{tabular}

Table-III. Associated Craniomaxillofacial injuries

\section{DISCUSSION}

In this prospective study males are predominantly affected as seen in most of trauma patients. Studies carried out by Balasubramanian ${ }^{10}$ showed $100 \%$ involvement of males in frontal bone fractures. Study of Hwang et al ${ }^{11}$ also showed high number of male patients being affected.

Study of Giovanni et $\mathrm{al}^{12}$ describes high number of patients in $4^{\text {th }}$ decade of life with peak age range of 31.5 years, this data also supports our research results where we also found majority of patients in $4^{\text {th }}$ decade of life.

RTA was seen as most contributing etiological 
factor in this current study which is in agreement with Balasubramanian 10 and Giovanni et al. ${ }^{12}$ While Vijay $\mathrm{M}$ et $\mathrm{al}^{15}$ documented assault as the most contributing factor.

Isolated fracture of the anterior table is the most common type of frontal bone injury. Anterior table fractures constituted $38.3 \%$ of cases reported by Rodriguez et al. ${ }^{3}$ Gossman et $\mathrm{al}^{13}$ in their series reported anterior table fractures as the most common constituting $50 \%$ of all cases. Isolated anterior table fractures were also found in $72.5 \%$ of cases in a series reported by El Khatib et al. ${ }^{14}$ Our study also shows majority of patients with anterior table fracture followed by combination fractures. Fractures of posterior table are rarely seen in most of the data seen worldwide.

Frontal bone fractures mostly occurs in combination with craniomaxillofacial injuries like NOE, ZMC, Lefort fractures, orbital floor, nasal bone and sometimes with mandible. Here we have found large amount of patients of frontal bone associated with naso-orbito-ethmoid fractures, which is similar to data provided by Giovanni at al. ${ }^{12}$

\section{CONCLUSION}

Fractures involving frontal bone is rather rare because of its protected location. This study concludes that RTA is the most contributing factor of frontal bone fracture at tertiary care hospital of Hyderabad. Fractures involving anterior table fracture are frequently seen. It is also concluded that these fractures rarely occur in isolation and mostly seen with NOE type of craniomaxillifacial trauma.

\section{Copyright@ 24 Sep, 2018.}

\section{REFERENCES}

1. Surya Rao RVM, Durairaj AR, Sundaramurthy N, Jesudasan JS. Frontal bone fractures - a report of three different methods of fixation: A case series. Int Surg J 2017; 4:3162-5.

2. LUCE EA. Frontal sinus fractures: Guideline to management. Plast Reconstr Surg 1987; 80: 500-508.
3. Rodriguez ED, Stanwix MG, Nam AJ, St Hilaire $H$, Simmons OP, Christy MR, et al. Twenty-six-year experience treating frontal sinus fractures: A novel algorithm based on anatomical fracture pattern and failure of conventional techniques. Plast Reconstr Surg 2008; 122:1850-66.

4. Smith TL, Han JK, Loehrl TA, Rhee JS. Endoscopic management of the frontal recess in frontal sinus fractures: A shift in the paradigm? Laryngoscope 2002; $112: 784-90$

5. The management of frontal sinus fractures. Tiwari $P$, Higuera S, Thornton J, Hollier LH.J Oral Maxillofac Surg. 2005 Sep; 63(9):1354-60

6. Wallis A, Donald PJ. Frontal sinus fractures: A review of 72 cases. Laryngoscope 1988; 98:593-598

7. Strong EB, Sykes JM. Frontal sinus and nasoorbitoethmoid complex fractures. In: Papel ID, ed. Facial Plastic Reconstructive Surgery. 2nd ed. New York: Thieme Medical Publishers; 2002:747-758

8. Perry M. Maxillofacial trauma - developments, innovations and controversies. Injury 2009; 40:12521259.

9. Kamoshima Y, Terasaka S, Nakamaru Y, Takagi D, Fukuda S, Houkin K. Giant frontal mucocele occurring 32 years after frontal bone fracture: A case report. Case Rep Neurol 2012; 4:34-7.

10. Balasubramanian T. Fracture frontal bone and its management. Otalar online Jr 2013; 3(1):1-11.

11. Hwang $\mathrm{K}$ et al. Analysis of facial bone fractures: An 11-year study of 2,094 patients. Indian J Plast Surg 2010; 43(1):42-49

12. Giovanni $G$ et al. Analysis of 158 frontal sinus fractures: Current surgical management and complications. Journal of Cranio-Maxillofacial Surgery (2000) 28, 133-139

13. Gossman DG, Archer SM, Arosarena O. Management of frontal sinus fractures: A review of 96 cases. Laryngoscope 2006; 116:1357-62.

14. El Khatib K, Danino A, Malka G. The frontal sinus: A culprit or a victim? A review of 40 cases. J Craniomaxillofac Surg 2004; 32:314-7.

15. Ravindra VM, Neil JA, Shah LM, Schmidt RH, Bisson EF. Surgical management of traumatic frontal sinus fractures: Case series from a single institution and literature review. Surg Neurol Int 2015; 6:141. 


\begin{tabular}{|c|c|c|c|}
\hline \multicolumn{4}{|c|}{ AUTHORSHIP AND CONTRIBUTION DECLARATION } \\
\hline Sr. \# & Author-s Full Name & Contribution to the paper & Author $=$ s Signature \\
\hline 1 & Salman Shams & $\begin{array}{l}\text { Principal author, Data } \\
\text { collection, Analysis. }\end{array}$ & \\
\hline 3 & Abdul Ghafar Shaikh & Data collection, Results. & \\
\hline 4 & Anand Kumar & References. & \\
\hline
\end{tabular}

